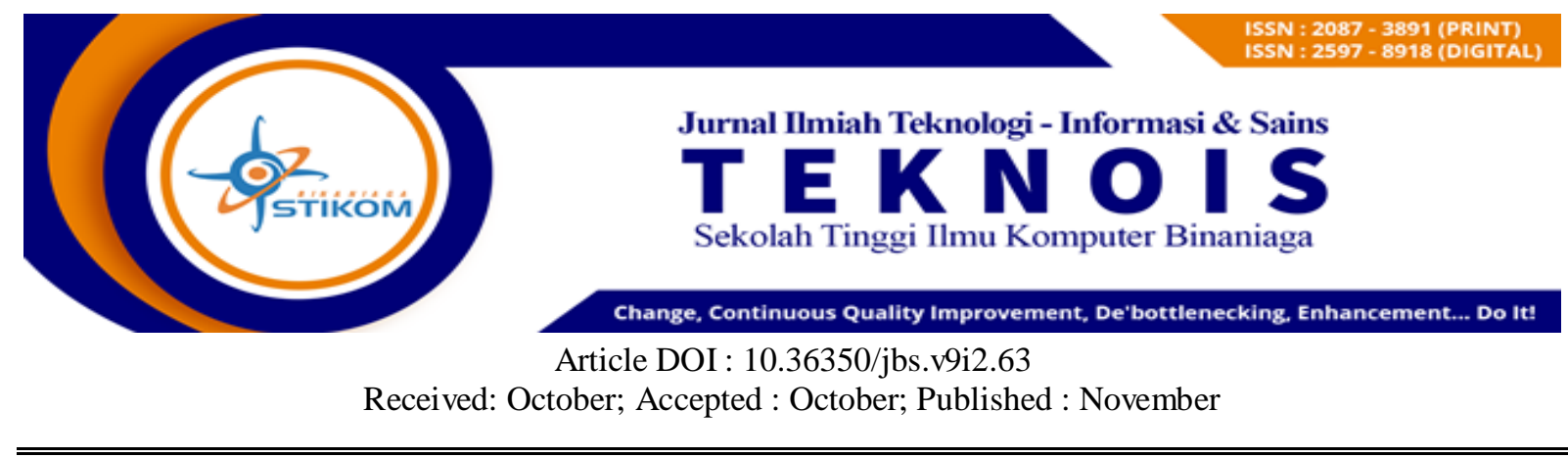

\title{
Penerapan metode hierarchical agglomerative clustering berbasis single linkage untuk pengelempokan judul skripsi
}

\author{
Irmayansyah $^{1^{*}}$, Siti Khaosaroh ${ }^{2}$ \\ ${ }^{1}$ Sistem Informasi/STIKOM Binaniga \\ Email: irma@ stikombinaniaga.ac.id \\ ${ }^{2}$ Sistem Informasi/STIKOM Binaniga \\ Email: sitikhaosaroh@gmail.com
}

\begin{abstract}
The thesis can be grouped by topic and method. The results of the grouping of the thesis can show how the suitability of the topic with the research method. This research grouped the thesis of the STIKOM Binaniaga Bogor Information System Study Program. The increase in thesis research has led to more and more students who are likely to take research that is almost similar in terms of themes, objects, or methods with previous research. This study conducted a thesis clustering of Information Systems Study Program students using the Hierarchical Agglomerative Clustering algorithm based on the topics and methods contained in the title. To determine the suitability of the topic with the method carried out the process of calculating the distance between objects using Manhattan Distance. The shortest thesis method is the method that best suits the topic. From the results of the process of calculating the distance between the data generated the closest distance of 1, so that it can be seen the order of suitability of the method on the chosen topic in accordance with the results of calculations using the single linkage method, the results of these calculations are then implemented on the screening title submission system. The test results of the thesis title submission system obtained a percentage of a feasibility level of $82 \%$.
\end{abstract}

Keywords: Manhattan Distance; Single Linkage; Hierarchical Agglomerative Clustering.

\section{ABSTRAK}

Skripsi dapat dikelompokkan berdasarkan topik dan metode. Hasil pengelompokkan skripsi dapat memperlihatkan bagaimana pola kesesuaian topik dengan metode penelitian. Penelitian ini mengelompokkan skripsi Program Studi Sistem Informasi STIKOM Binaniaga Bogor. Semakin bertambahnya penelitian skripsi menyebabkan semakin banyak pula mahasiswa yang kemungkinan mengambil penelitian yang hampir mirip baik dari sisi tema, objek, atau metode dengan penelitian sebelumnya. Penelitian ini melakukan clustering Judul Skripsi mahasiswa Program Studi Sistem Informasi dengan menggunakan algoritma Hierarchical Agglomerative Clustering berdasarkan topik dan metode yang terdapat dalam judul. Untuk mengetahui kesesuaian topik dengan metode dilakukan proses menghitung jarak antar objek dengan menggunakan Manhattan Distance. Metode skripsi yang paling pendek jaraknya adalah metode yang paling sesuai dengan topiknya. Dari hasil proses perhitungan jarak antar data dihasilkan jarak terdekat sebesar 1, sehingga dapat diketahui urutan kesesuaian metode pada topik yang dipilih sesuai dengan hasil perhitungan menggunakan metode single linkage, Hasil dari perhitungan tersebut kemudian di implementasikan pada sistem pengajuan judul skrpsi. Hasil uji dari sistem pengajuan judul skripsi tersebut diperoleh presentase tingkat kelayakan sebesar $82 \%$.

Keywords: Manhattan Distance; Single Linkage; Hierarchical Agglomerative Clustering. 


\section{A. PENDAHULUAN}

Sekolah Tinggi Ilmu Komputer Binaniaga atau disingkat STIKOM BINANIAGA adalah salah satu perguruan tinggi swasta di kota Bogor. Sesuai dengan namanya STIKOM BINANIAGA adalah perguruan tinggi yang mengkhususkan diri di rumpun ilmu komputer dengan membina dua program studi jenjang strata 1 yaitu sistem Informasi dan Teknik Informatika. Setiap tahunnya STIKOM BINANIAGA meluluskan mahasiswa, yang berarti penelitian skripsi mahasiswa akan bertambah setiap tahunnya.

Menjelang semester akhir, program studi merekomendasikan beberapa topik yang harus dipilih oleh mahasiswa sebagai bidang konsentrasi dalam penyusunan skripsi. Topik ini akan membantu mahasiswa dalam membuat judul skripsi, yang didalamya termuat pula metode yang dipakai dalam penyusunan skripsi. Setelah merekomendasikan beberapa topik skripsi kepada mahasiswa, program studi akan menerima pengajuan judul skripsi dari mahasiswa, tugas program studi adalah memilih judul mana yang akan diterima sebagai judul skripsi dan judul mana yang ditolak. Untuk menentukan apakah judul tersebut diterima atau tidak, ada 2 (dua) faktor yang menjadi pertimbangan program studi, yaitu: Kesesuaian metode dengan topik yang dipilih dan terdapat kesamaan antara Judul yang diajukan dengan judul skripsi sebelumnya. Untuk memastikan ke dua faktor di atas program studi perlu melakukan evaluasi dan kontrol terhadap judul skripsi sebelumnya, evaluasi disini adalah melihat kembali judul skripsi sebelumnya apakah judul yang telah diajukan oleh mahasiswa telah sesuai atau belum dengan topik dan metode yang telah dipilih. Adanya evaluasi mengenai kesesuaian judul dengan topic dan metode dapat membantu dalam memastikan apakah skripsi yang akan disusun mahasiswa sesuai dengan program studinya atau tidak. Tujuan dilakukannya penelitian ini adalah Untuk mendapatkan kecenderungan kelompok pilihan topik dan metode dalam pengajuan judul skripsi serta untuk Mengembangkan sistem pengajuan judul skrpsi

Penelitian mengenai pengelompokan skripsi sebetulnya sudah banyak dilakukan dan banyak pula metode-metode yang telah digunakan salah satunya adalah hasil penelitian dari Herny Februariyanti dan Dwi Budi Santoso dari Universitas STIKUBANK program studi sistem informasi dengan judul "hierarchical agglomerative clustering untuk pengelompokan skripsi mahasiswa" yang menyandingkan metode hierarchical agglomerative clustering dengan algoritma dice coefisien dan ada pula penelitian dari Lynda Rahmawati, Sari Widya Sihwi dan Esti Suryani dari Universitas Sebelas Maret jurusan Informatika dengan judul analisa clustering menggunakan metode k-means dan hierarchical clustering.

Penelitian yang akan dilakukan yaitu terkait pengelompokan skripsi sebagai bahan evaluasi dan kontrol mengenai kesesuaian judul skripsi dengan topik dan metode yang dipilih mahasiswa dalam menyusun skripsi dengan menggunakan metode Hierarchical Agglomerative Clustering Berbasis Single linkage. Dari penerapan hierarchical agglomerative clustering dengan metode single linkage ini diharapkan mampu mengelompokan judul skripsi yang nantinya membantu dalam mengevaluasi judul skripsi sebelumnya untuk mengetahui kesesuaian judul skripsi dengan topik dan metode skripsi yang di pilih serta mampu membantu dalam mengontrol judul skripsi yang diajukan

\section{B. METODE}

Dalam penelitian ini terdapat dua tujuan yang hendak dicapai, tujuan yang pertama adalah Untuk mendapatkan kecenderungan kelompok pilihan topik dan metode dalam pengajuan judul skripsi dengan meminimalisir kemiripan judul skripsi melalui perhitungan jarak kemiripan judul skripsi, judul skripsi dianggap sangat mirip jika memiliki jarak terdekat atau memiliki nilai jarak minimal.Selain itu dari kemiripan judul skripsi tersebut akan muncul keberagaaman topik, objek dan metode skripsi. Tujuan yang kedua adalah untuk Mengembangkan sistem pengajuan judul skrpsi

Untuk dapat mewujudakan tujuan tersebut digunakan dua buah metode / model, yaitu metode / model konseptual dan prosedural, metode konseptual merupakan metode pemecahan masalah 
secara konsep atau teori. Model konseptual yang diajukan dalam penelitian ini yaitu metode hierarchical agglomerative clustering dengan metode single linkage. Menurut Prasetyo (2014; p245) mengatakan "Dalam statistik pengelompokan berbasis hierarki adalah metode analisis clustering yang berusaha membangun sebuah hierarki clustering. Strategi untuk pengelompokan berbasis hierarki umumnya jatuh kedalam dua jenis, yaitu agglomerative dan divisif". Agglomerative merupakan metode pengelompokan berbasis hierarki dengan pendekatan buttom up, yaitu proses pengelompokan dimulai dari masing-masing data sebagai satu buah cluster. kemudian cara reklusif mencari cluster terdekat sebagai pasangan untuk bergabung sebagai satu cluster yang lebih besar (Prasetyo, 2013).Proses tersebut diulang terus sehingga tampak bergerak ke atas membentuk hierarki. Cara ini membutuhkan suatu parameter kedekatan cluster. Menurut Prasetyo (2014; p246), ada tiga teknik kedekatan yang digunakan Hierarchical Agglomerative Clustering dalam pembahasannya yaitu single linkage (jarak terdekat), complete linkage (jarak terjauh), dan average (jarak rerata). Single Linkage memberikan hasil bila cluster-cluster digabungkan menurut jarak antara anggota-anggota yang paling dekat diantara dua cluster. Complete Cluster terjadi bila kelompok- kelompok digabungkan menurut jarak antara anggotaanggota yang paling jauh diantara dua cluster. Untuk Average Linkage digabungkan menurut jarak rata-rata antara pasangan -pasangan anggota masing pada himpunan di antara dua cluster.

Metode prosedural diterapkan dalam rangka mengembangkan sistem pengajuan judul skrpsi, adapun metode yang digunakan adalah metode prototype. Metode prototype sesuai digunakan untuk mengembangkan sebuah perangkat yang akan dikembangkan kembali. Metode ini dimulai dengan pengumpulan kebutuhan pengguna, dalam hal ini pengguna dari perangkat yang dikembangkan adalah Program Studi. Kemudian membuat sebuah rancangan kilat yang selanjutnya akan dievaluasi kembali sebelum diproduksi secara benar. Adapun Prosedur pengembangan dalam penelitian yang akan dilakukan dapat digambarkan pada gambar 1

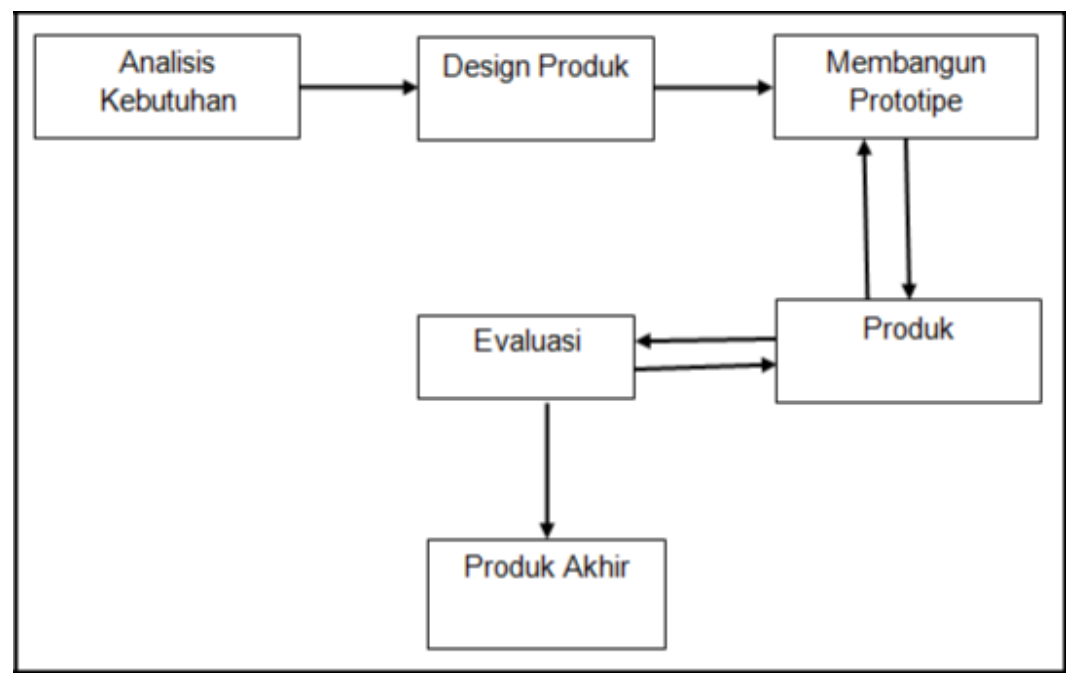

Gambar 1. Prosedur Pengembangan

Variabel yang digunakan dalam penelitian ini adalah variabel Topik dan Model. Topik merupakan merupakan tema skripsi sedangkan metode /model adalah merupakan metode yang digunakan mahasiswa dalam menyusun skripsi. Teknik pengumpulan data yang dilakukan dalam penelitian ini meliputi: pengumpulan dokumentasi, wawancara dan penyebaran angket/kuisioner. Pengumpulan dokumen dilakukan dalam rangka mengidentifikasi permasalahan dan kebutuhan data yang nantinya diperlukan dalam pengembangan adapun dokumen yang dikumpulkan adalah Data Judul Skripsi tahun periode 2015/2016 yaitu berupa file data judul skripsi yang ada di perpustakaan STIKOM Binaniaga diperoleh atas izin pertugas perpustakaan STIKOM Binaniaga,Informasi yang diperoleh pada dokumen tersebut adalah judul skripsi,nama penyusun,program studi dan tahun penyusunan.Selain data judul skripsi yang terdapat di perpustakaan STIKOM Binaniaga,juga diperoleh dokumen daftar topik skripsi pada tahun 2015/2016, Wawancara dilakukan di Kampus STIKOM Binaniaga dengan narasumber Ketua Program Studi, informasi yang didapatkan adalah mengenai prosedur pengajuan judul skripsi 
yang selama ini berjalan dan bagaimana proses pengambilan keputusan mengenai persetujuan judul skripsi yang di ajukan oleh mahasiswa. Penyebaran angket/kuisioner dalam penelitian ini digunakan untuk menilai kepuasan pengguna terhadap sistem yang diujikan, pengujian dilakukan dengan menyebarkan angket/kuisioner kepada kelompok kecil yaitu Mahasiswa semester akhir jurusan Sistem Informasi STIKOM Binaniaga Bogor. Penyebaran kuisioner diberikan kepada responden yang dipilih dari populasi untuk kemudian dilakuan pemilihan sample dengan menerapkan metode slovin dengan teknik stratified sampling, jumlah populasi yang ada berjumlah 107 orang yang berasal dari 4 kelompok yaitu 11 orang berasal dari kelompok mahasiswa kelas reguler A, 8 orang berasal dari kelompok mahasiswa kelas regular B, 33 orang berasal dari kelompok mahasiswa kelas $\mathrm{C}$, dan 55 orang berasal dari kelompok mahasiswa kelas D. Jumlah sampel yang dihasilkan yaitu berjumlah 52 responden yang diperoleh dari hasil penerapan metode slovin, hasil tersebut digunakan untuk memperoleh distribusi responden pada masing-masing strata atau kelompok (stratified sampling). Adapun cara perhitungan penentuan sampel setiap kelompok adalah sebagai berikut:

Kelas Reguler $A=(11: 107)$ x $52=5$ responden

Kelas Reguler $\mathrm{B}=(8: 107)$ x $52=4$ responden

Kelas Reguler $\mathrm{C}=(33: 107) \times 52=16$ responden

Kelas Reguler D $=(55: 107) \times 52=27$ responden

Jumlah $=52$ responden

Kuisioner yang telah diisi oleh responden, selanjutnya akan di olah menggunakan teknik persentase kelayakan. Hasil presentase digunakan untuk memberikan jawaban atas kelayakan sistem informasi yang dikembangkan. Adapun rumus yang digunakan adalah sebagai berikut:

$$
\text { Persentase kelayakan }=\frac{\text { Skor yang diobservasi }}{\text { Skor yang diharapkan }} \times 100 \%
$$

Menurut Arikunto (2009, p.44), pembagian kategori kelayakan ada lima. Skala ini memperhatikan rentang dari bilangan presentase. Nilai maksimal yang diharapkan adalah $100 \%$ dan minimum 0\%. Pembagian rentang kategori kelayakan menurut Arikunto (2009, p.44), dapat dilihat pada tabel 1 .

Tabel 1. Kategori Kelayakan (Arikunto)

\begin{tabular}{|c|c|}
\hline Presentase Pencapaian & Interpretasi \\
\hline$<21 \%$ & Sangat Tidak Layak \\
\hline $21 \%-40 \%$ & Tidak Layak \\
\hline $41 \%-60 \%$ & Cukup layak \\
\hline $61 \%-80 \%$ & Layak \\
\hline $81 \%-100 \%$ & Sangat Layak \\
\hline
\end{tabular}

\section{HASIL DAN PEMBAHASAN}

\section{Hasil}

Untuk membantu proses pengambilan keputusan pengajuan judul skripsi dibangun sebuah system informasi yang menerapkan logika Hierarchical Agglomerative Clustering Berbasis Single Linkage untuk meng-clusterkan judul skripsi berdasarkan topik dan metode skripsi, cluster tersebut dapat membagi informasi yang berada pada data yang ada dan dibentuk kedalam sebuah aturan dimana aturan tersebut akan menjadi cluster baru. Gambar 2 menunjukan tahapan untuk mengclusterkan judul skripsi berdasarkan topik dan metode skripsi menggunakan metode Hierarchical Agglomerative Clustering Berbasis Single Linkage

Persiapan data dilakukan dengan memilih atribut yang nantinya akan digunakan untuk proses modeling. Atribut yang telah dipilih nantinya akan disimpan kembali kedalam dataset yang baru yang siap untuk diproses kedalam proses modeling. Adapun Atribut yang dipilih pada penelitian ini adalah NPM, Nama, Topik, Judul dan Model. Kemudian dilakukan transformasi data dengan memindahkan atribut yang telah dipilih pada proses pemilihan data untuk dipindahkan pada dataset baru yang nantinya akan diproses pada tahapan selanjutnya. Dalam penerapan metode Hierarchical Agglomerative clustering jumlah data sama dengan jumlah cluster. Adapun tahapan yang harus dilakukan menerapkan metode ini adalah menentukan (C)2019 Teknois : Jurnal IImiah Teknologi Informasi dan Sains. Copyrights All rights reserved 
atribut atau variabel data kemudian membuat matrik jarak menggunakan Manhattan Distance, setelah matrik terbentuk selanjutnya dari matrik tersebut pilih jarak data yang mempunyai selisih terkecil kemudian pisahkan menjadi satu cluster dengan menggunakan metode Single Linkage. Single linkage menghasilkan cluster-cluster yang digabungkan menurut jarak antara anggota-anggota yang paling dekat diantara dua cluster, kedekatan diantara dua cluster ditentukan dari jarak terdekat (terkecil) diantara pasangan dari dua cluster berbeda, setelah jarak minimal antar cluster di temukan maka baris dan kolom matrik akan di seleksi kemudian menambahkan satu baris dan kolom untuk di isi dengan cluster yang telah digabungkan,begitu seterusnya sampai tersisa dua buah cluster dan membentuk cluster tunggal dari semua data dengan jarak data yang paling terdekat. Setelah proses matrik Manhattan Distance dan Single Linkage selesai langkah terakhir adalah meringkas data-data yang masuk kedalam cluster dengan jarak terdekat kemudain membuat kesimpulan tentang jarak terdekat dari cluster tersebut.

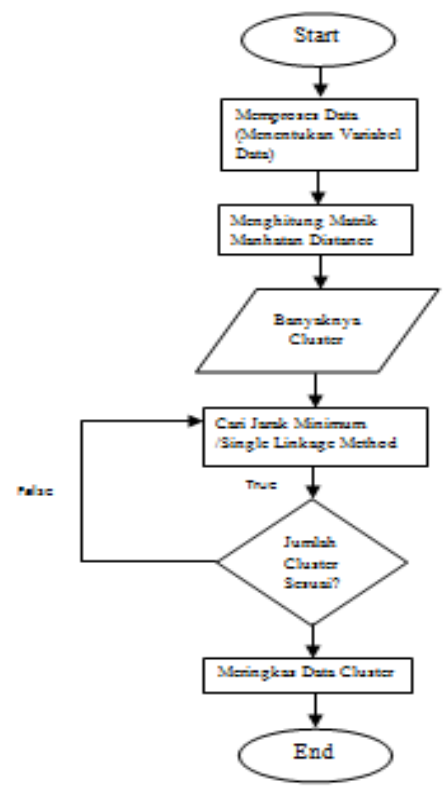

Gambar 2. Flowchart Agglomerative Clustering - Single Linkage

Untuk menerapkan metode clustering dengan Agglommerative Clustering-Single Linkage Kedalam sistem informasi pengajuan judul skripsi dilakukan tahapan - tahapan

a. Analisis Kebutuhan dan Hasil Analisis Kebutuhan Analisis Kebutuhan

Tahap ini dilakukan dengan mengumpulkan kebutuhan yang dilanjutkan dengan analisis kebutuhan untuk memperoleh hasil analisis yang akan diterapkan dalam pengembangan sistem informasi pengajuan judul skripsi, analisis kebutuhan dilakukan dengan cara:

1) Pengumpulan dokumen

Pengumpulan dokumen dilakukan dalam rangka mengidentifikasi permasalahan dan kebutuhan data yang nantinya diperlukan dalam pengembangan adapun dokumen yang dikumpulkan adalah Data Judul Skripsi tahun periode 2015/2016 yaitu berupa file data judul skripsi yang ada di perpustakaan STIKOM Binaniaga. Data tersebut diperoleh atas izin petugas perpustakaan. Informasi yang diperoleh dari dokumen tersebut adalah judul skripsi, nama penyusun, program studi dan tahun penyusunan.Selain data judul skripsi yang terdapat di perpustakaan STIKOM Binaniaga, dokumen daftar topik skripsi pada tahun 2015/2016 juga digunakan untuk analisa pada pengembangan ini

2) Wawancara

Wawancara dilakukan di Kampus STIKOM Binaniaga dengan narasumber ketua program studi. informasi yang diperoleh dari wawancara tersebut adalah terkait prosedur pengajuan judul skripsi yang selama ini berjalan dan bagaimana proses pengambilan keputusan mengenai persetujuan judul skripsi yang di ajukan oleh mahasiswa. Dari hasil wawancara tersebut diketahui bahwa pada pengajuan Judul 
Skripsi, mahasiswa harus mengisi lembar pengajuan judul skripsi yang berisi topik skripsi, judul skripsi dan dua nama dosen pembimbing yang akan dipilih mahasiswa dalam membimbing penyusunan skripsi mahasiswa sampai akhir, setelah mengisi lembar pengajuan judul skripsi,mahasiswa menyerahkan lembar pengajuan judul skripsi tersebut kepada program studi.Berdasarkan lembar pengajuan judul skripsi yang di ajukan mahasiswa, ketua program studi memberikan persetujuan pengajuan judul skripsi mahasiswa, Berdasarkan hasil wawancara yang dilakukan dapat disimpulkan bahwa Program studi tidak bisa melakukan evaluasi dan kontrol terkait kesesuaian judul yang diajukan mahasiswa dengan topic dan metode sehingga perlu dikembangkan sistem informasi pengajuan judul skripsi dengan proses bisnis yang berbeda dengan yang sebelumnya, pada proses bisnis yang akan di kembangkan ini,program Studi dalam proses pengambilan keputusan dapat melakukan evaluasi dan kontrol melalui data judul skripsi pada sistem,proses evaluasi dan kontrol dilakukan dengan melihat kesesuaian metode dengan topic dan metode yang telah di tentukan oleh sistem melalui metode yang diterapkan.Evaluasi ini mampu menjadi bahan pertimbangkan untuk program studi dalam sistem pengambilan keputusan mengenai pengajuan judul skripsi. Adapun pemodelan pada sistem yang dikembangkan dapat dilihat pada gambar 3 .

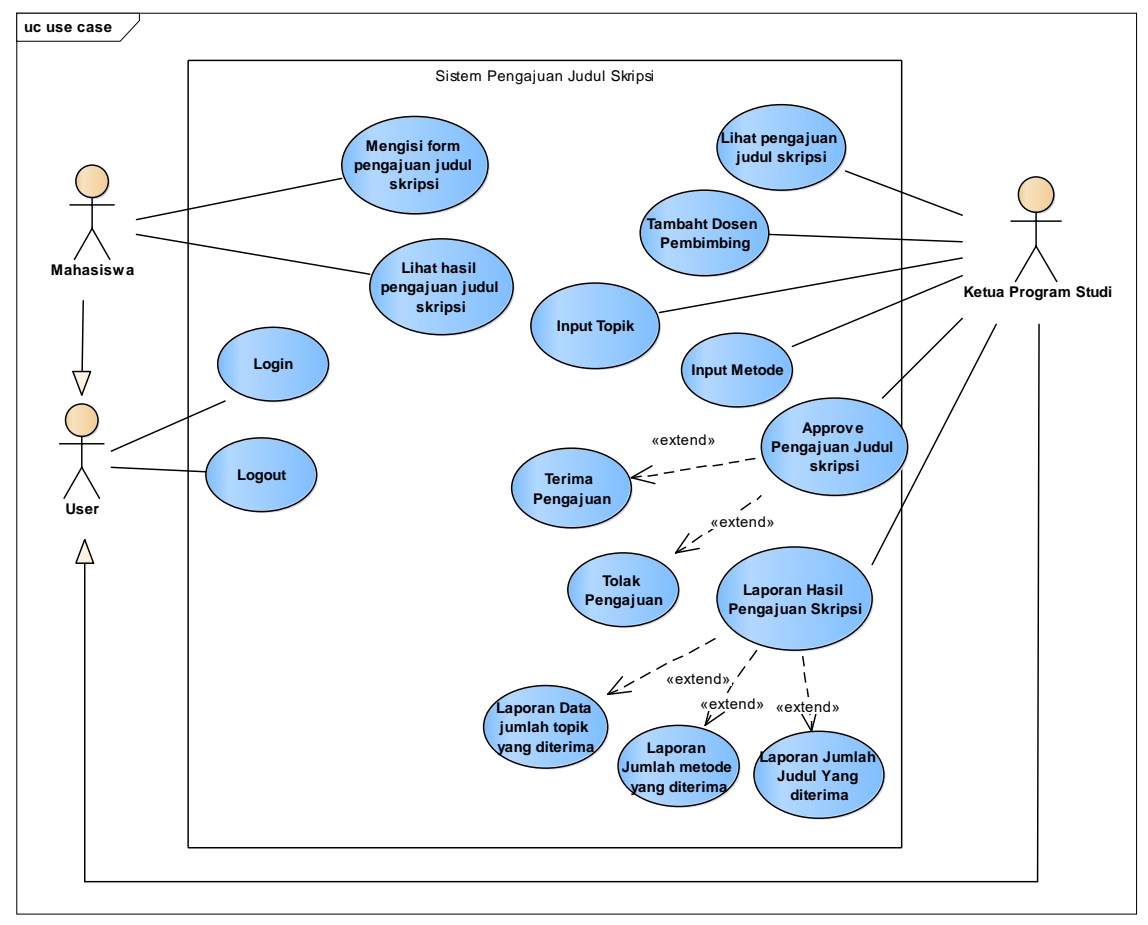

Gambar 3. Usecase

Gambar 3 menjelaskan terdapat 2 aktor pengguna dalam sistem pengajuan judul skripsi yaitu mahasiswa dan ketua program studi,dalam mengakses sistem ini kedua aktor tersebut harus melakukan login terlebih dahulu dengan menggunakan id dan password masing - masing. Ketika mahasiswa berhasil mengakses sistem, maka mahasiswa dapat melakukan kegiatan mengisi form pengajuan judul skripsi.dan dapat melihat hasil keputusan prodi mengenai pengajuan judul skripsi yang telah di ajukan, apakah judul yang di ajukan mendapatkan persetujuan prodi atau tidak. Aktor Program studi dapat melakukan kegiatan melihat pengajuan judul skripsi, melihat kesesuaian metode dengan topik jika metode sesuai maka pengajuan di terima jika metode tidak sesuai dengan topik atau metode yang dipakai telah banyak digunakan mahasiswa lain maka pengajuan judul di tolak dan mahasiswa diharuskan melakukan pengajuan ulang,selain itu ketua program studi juga dapat menginputkan topik dan metode, fungsi ini dipersiapkan jika terjadi penambahan topik yang direkomdasikan pihak kampus 
Volume 9 Number 2 November 2019 Page. 53-64

Journal Homepage : http://teknois.stikombinaniaga.ac.id/index.php/JBS

DOI Link : http://doi.org/10.36350/jbs.v9i2

kepada mahasiswa, Adapun bentuk keluaran yang dihasilkan adalah laporan hasil pengajuan skripsi yang terdiri atas laporan pengajuan topik diterima, laporan metode yang diterima dan jumlah pengajuan judul yang di terima. Dengan adanya fungsi fungsi tersebut diharapkan dapat membantu program studi dalam pengambilan keputusan pengajuan judul skripsi

b. Membangun Prototipe

1) Interface sistem Pengajuan Judul Skripsi

Setelah mengumpulkan data yang dibutuhkan untuk membangun sistem Pengajuan Judul Skripsi, selanjutnya adalah tahap membangun prototype

a) Menu Login

Halaman login digunakan untuk masuk ke dalam halaman utama dengan validasi username dan password yang terdaftar didalam sistem.

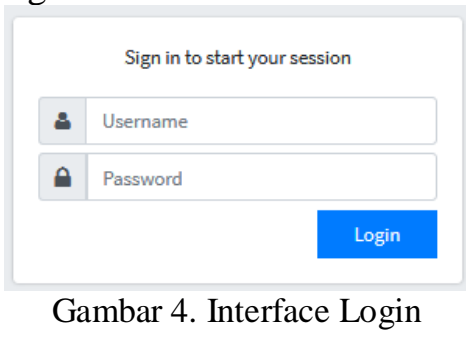

b) Form menu utama prodi

Form menu utama prodi terdiri dari menu approve judul skripsi, tambah dosen pembimbing, report dan perhitungan. Menu utama ini hanya dapat diakses oleh prodi

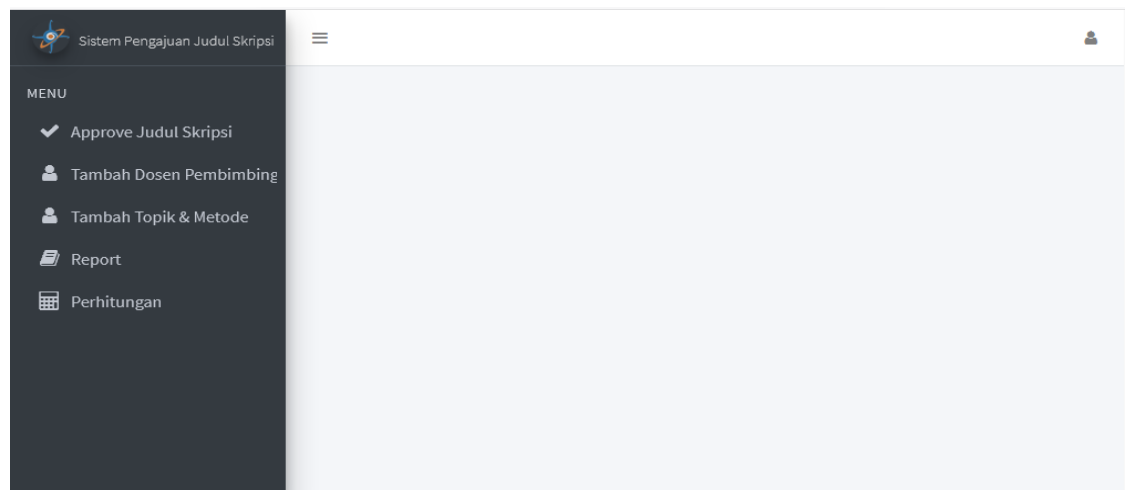

Gambar 5. Interface menu utama prodi

c) Form approve pengajuan judul skripsi

Form approve pengajuan judul skripsi ini digunakan untuk membuat keputusan atas diterima atau ditolak pengajuan judul mahasiswa, form ini hanya bisa diakses oleh prodi.

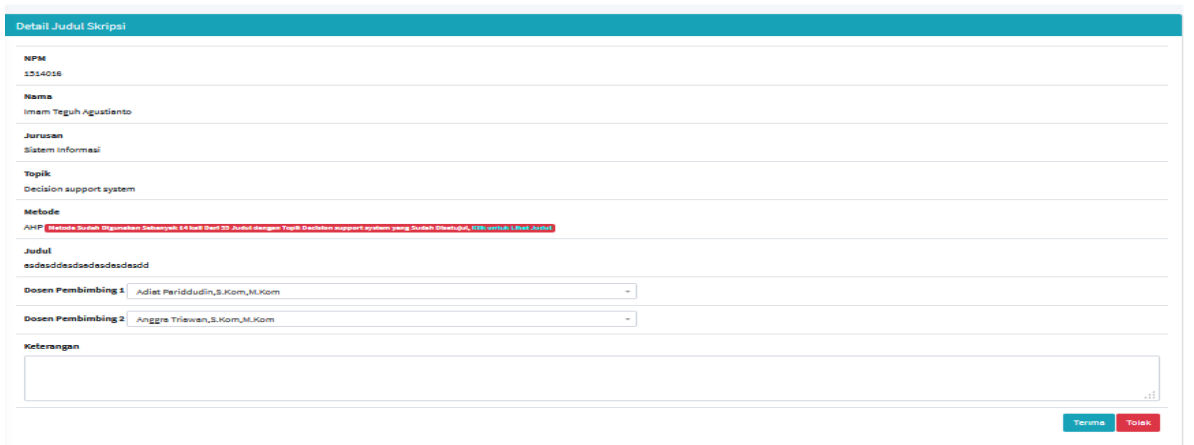

Gambar 6. Interface Form approve pengajuan judul skripsi 
Volume 9 Number 2 November 2019 Page. 53-64

Journal Homepage : http://teknois.stikombinaniaga.ac.id/index.php/JBS

DOI Link : http://doi.org/10.36350/jbs.v9i2

d) Form tambah Topik dan Metode

Form tambah topik dan metode digunakan untuk menambahkan daftar topik dan metode sebagai variabel form input pengajuan judul

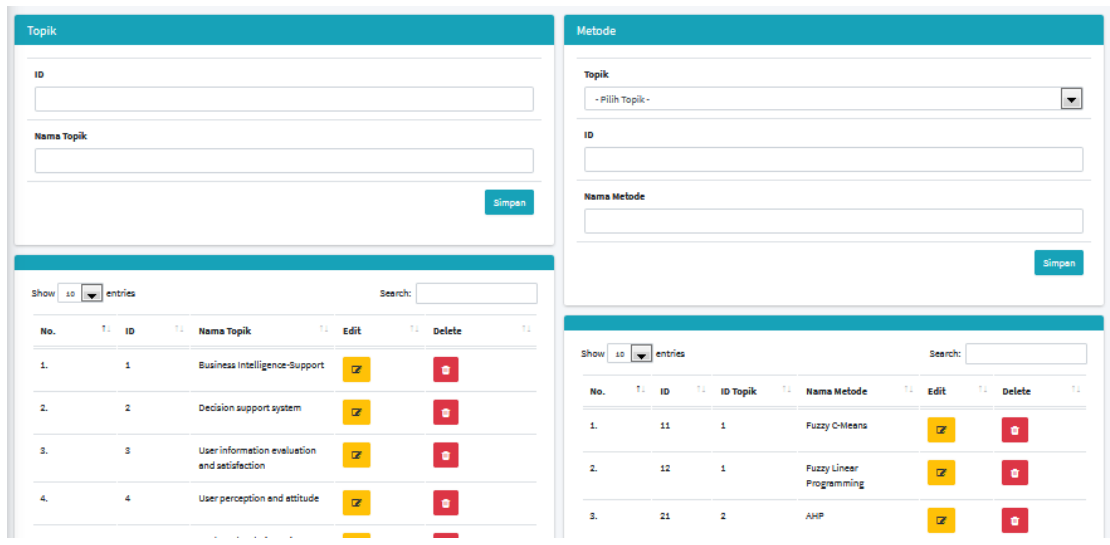

Gambar 7. Interface tambah topik dan metode

e) Form report judul yang diterima

Form report judul diterima digunakan untuk melihat jumlah judul yang telah diterima.

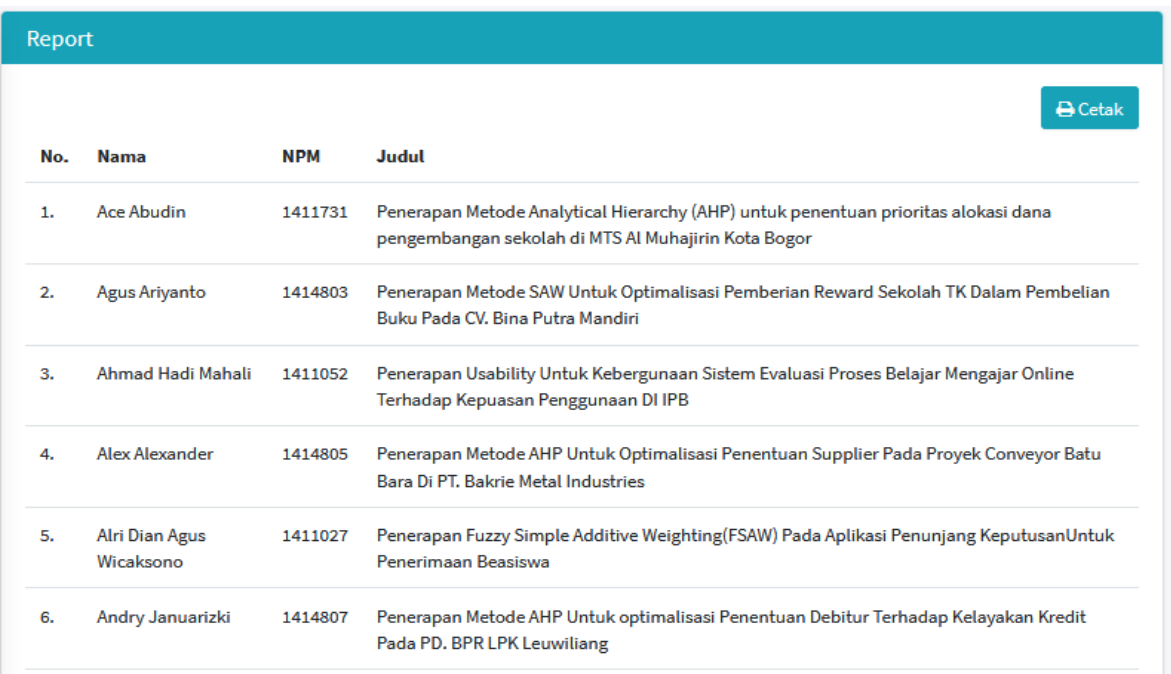

Gambar 8. Interface report judul diterima

f) Form report topik dan metode

Form report topik dan metode digunakan untuk melihat topik dan jumlah metode yang telah disetujui oleh prodi.

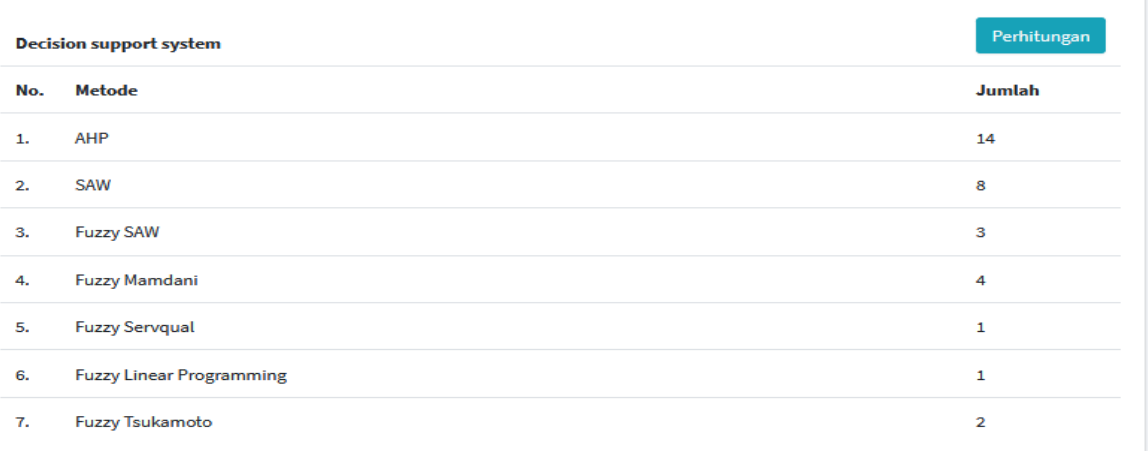

Gambar 9. interface report topik dan metode 
Volume 9 Number 2 November 2019 Page. 53-64

Journal Homepage : http://teknois.stikombinaniaga.ac.id/index.php/JBS

DOI Link : http://doi.org/10.36350/jbs.v9i2

g) Form Input perhitungan

Form report input digunakan untuk menginputkan variabel sehingga muncul hasil perhitungan metode

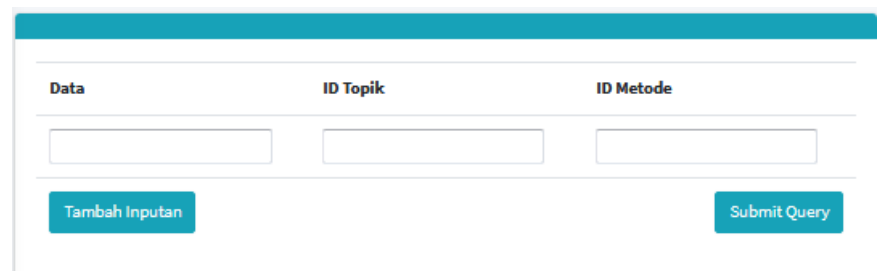

Gambar 10. Interface form input perhitungan

h) Form hasil pengajuan judul

Form hasil pengajuan judul digunakan untuk melihat hasil keputusan prodi mengenai diterima atau ditolak pengajuan judul skripsi yang telah di ajukan sebelumnya.

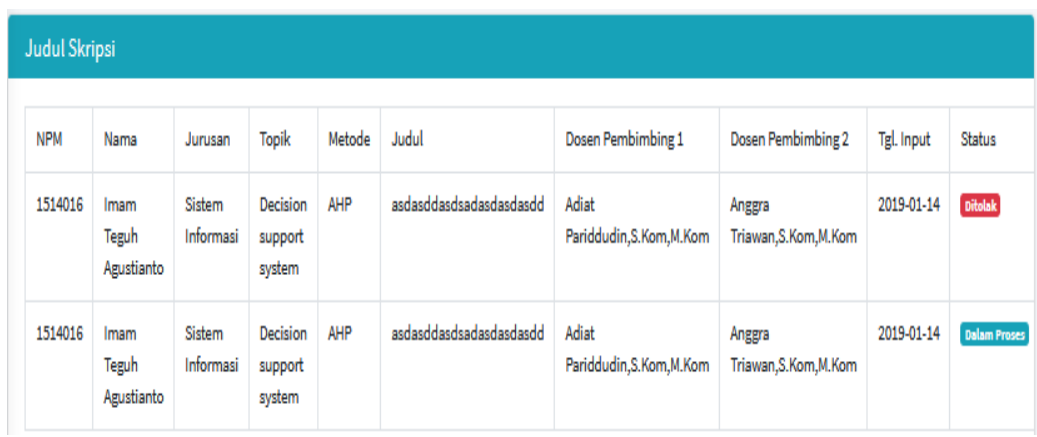

Gambar 11. interface hasil pengajuan judul

2) Struktur Sistem

Struktur sistem digambarkan menggunakan class diagram dan deployment diagram. Class diagram, menjelasakan class, paket, dan objek serta hubungan satu sama lain seperti containment, pewarisan, dan asosiasi. Deployement diagram menunjukkan tata letak sebuah sistem secara fisik, menampakkan bagian-bagian software yang berjalan pada bagian hardware yang digunakan untuk mengimplementasikan sebuah sistem dan hubungannya dengan komponen hardware yang digunakan dalam pembangunan sistem. Gambaran struktur sistem menggunakan class diagram dan deployment diagram dapat dilihat pada gambar 12 dan gambar 13.

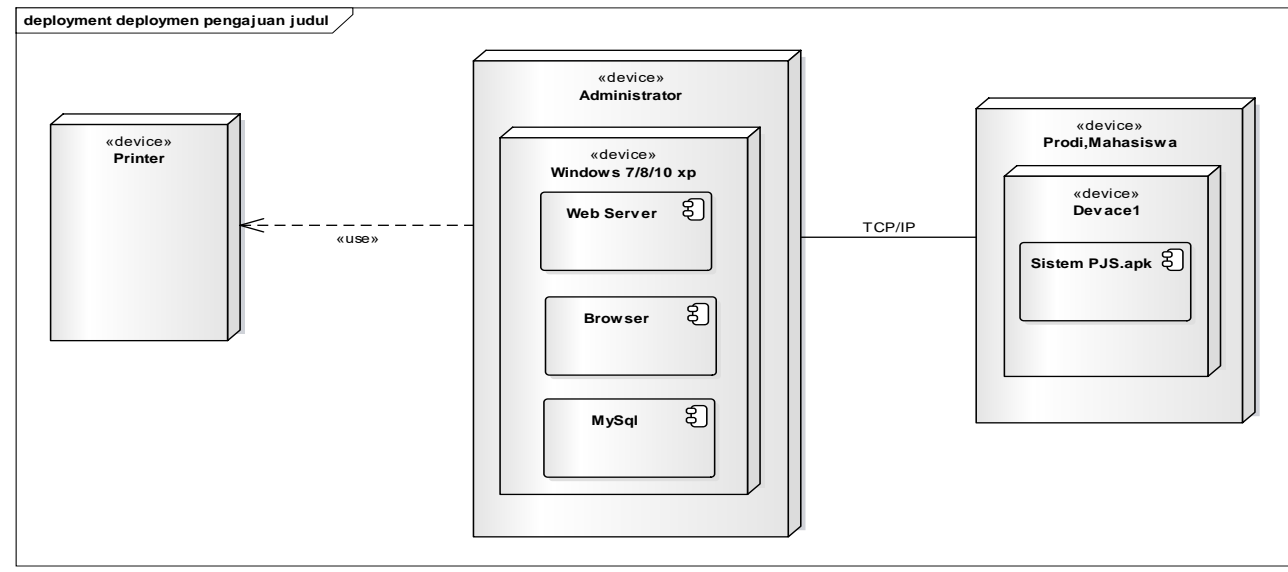

Gambar 12. deployment Diagram 
Volume 9 Number 2 November 2019 Page. 53-64

Journal Homepage : http://teknois.stikombinaniaga.ac.id/index.php/JBS

DOI Link : http://doi.org/10.36350/jbs.v9i2

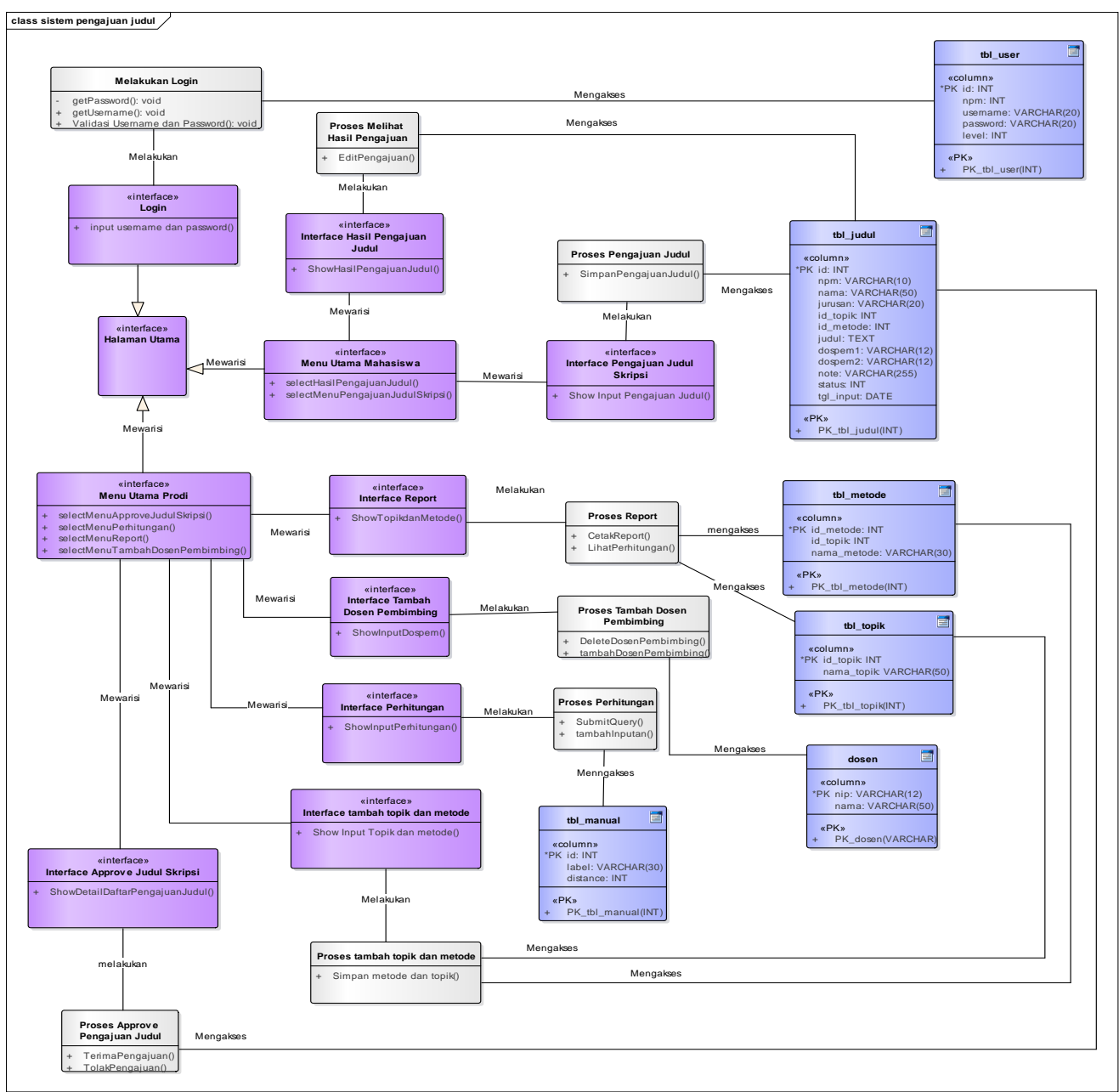

Gambar 13. Class Diagram

\section{Pembahasan}

Pengujian sistem informasi pengajuan judul skripsi dilakukan dengan menyebarkan kuisioner kepada 52 orang responden. Kuisioner yang disebarkan menggunakan instrument yang di bangun berdasarkan paket pertanyaan kuisioner PSSUQ (Post-Study System Usability Questionnaire). PSSUQ merupakan paket pertanyaan kuisioner yang berisi sebanyak 16 pertanyaan. Paket pertanyaan kuisioner ini memiliki tujuan untuk menilai kepuasan pengguna terhadap sistem yang diujikan. Pengukuran nilai yang digunakan menggunakan skala Likert bernilai 1 hingga 7, nilai 1 untuk menyatakan sangat tidak setuju dan nilai 7 untuk menyatakan sangat setuju. Tabel 2 menunjukan hasil pengujian sistem informasi pengajuan judul skripsi

Tabel 2. Pengujian Sistem Informasi

\begin{tabular}{|c|l|c|c|}
\hline No & Aspek Penilaian & Skor Observasi & Skor yang diharapkan \\
\hline 1 & Overall & 273 & 364 \\
\hline 2 & System Quality & 1648 & 1820 \\
\hline 3 & Information Quality & 1722 & 2184 \\
\hline 4 & Interface Quality & 1139 & 1456 \\
\hline \multicolumn{2}{r|}{ Jumlah } & 4782 & 5824 \\
\hline
\end{tabular}

Dari hasil data pengujian system informasi diperoleh hasil bahwa kelayakan system informasi yang dikembangkan memperoleh persentase kelayakan sebesar $82 \%$ yang berarti masuk dalam kategori sangat layak, persentase tersebut di peroleh dengan cara membandingkan jumlah total skor yang diobservasi dengan jumlah total skor yang diharapkan 


\section{KESIMPULAN}

Berdasarkan pada hasil penelitian yang telah dilakukan dapat ditarik beberapa kesimpulan sebagai berikut:

1. Metode Hierarchical Agglomerative Clustering Berbasis Single Linkage dapat digunakan untuk memudahkan dalam pendukung keputusan ketua program studi dalam mempertimbangkan kesesuaian judul dengan metode dan topik yang diajukan oleh mahasiswa melalui sistem pengajuan judul skripsi.

2. Dengan adanya sistem pengajuan judul skripsi ini memudahkan mahasiswa dalam proses pengajuan judul skripsi terutama pada saat memilih metode yang akan digunakan.

3. Persentase kelayakan sistem pengajuan tugas akhir yang diperoleh sebesar $82 \%$, yang bermakna sistem pengajuan judul skripsi yang dikembangkan dapat dikategorikan masuk ke dalam interpretasi sangat layak.

\section{E. DAFTAR PUSTAKA}

[1] Arifin , Z., \& Santosa, S. 2017. Klasterisasi Genre Cerpen Kompas Menggunakan Agglomerative Hierarchical Clustering-Single Linkage.Universitas Dian Nuswantoro

[2] Arikunto,S.2004.Evaluasi Program Pendidikan,Jakarta : Bumi Aksara

[3] Arikunto, S. 2009. Manajemen Penelitian, Jakarta : Rineka Cipta

[4] Christopher D., Prabhakar Raghavan, Hinrich Schutze, 2009, An Introduction to Information Retrieval, Cambridge: Cambridge University Presss.

[5] Elliott.2004.System Development Life Cycle.

[6] F. Februariyanti, H., \& Santoso, B. D. 2017. Hierarchical Agglomerative Clustering.Universitas STIKUBANK

[7] F. Handoyo, R., M, R. R., \& Nasution, S. M. 2014. Perbandingan Metode Clustering Menggunakan Metode Single Linkage Dan K-Means Pada Pengelompokan Dokumen.Universitas Telkom. Bandung

[8] FahmiAulia Ilham, 2016 , Pengembangan local e-government menggunakan usability engineering lifecycle dan evaluasi usability menggunakan kuisioner PSSUQ

[9] J. R. Lewis, "Psychometric Evaluation of the PSSUQ Using Data from Five Years of Usability Studies.," INTERNATIONAL JOURNAL OF HUMAN-COMPUTER INTERACTION, vol. 14, no.3\&4, pp. 463-488, 2002.

[10] Manalu, D. R. 2016. Pengujian Tingkat Kemiripan Skripsi Mahasiswa Dengan Algoritma Genetika Menggunakan Posi Formulation.Universitas Methodist Indonesia. Medan

[11] McLeod, Reymond,Jr \& schell,George P.2008.Sistem Informasi Manajemen.Terjemahan oleh Ali Akbar Yulianto dan Afia R.Fitriani. Jakarta

[12] Prasetyo, E. 2014. DATA MINING-Mengolah Data menjadi Informasi Menggunakan Matlab. Yogyakarta:Andi. ADDIN Mendeley Bibliography CSL_BIBLIOGRAPHY

[13] Pressman, R. S. 2012. Rekayasa Perangkat Lunak. Yogyakarta: Andi.

[14] Rahmawati , L., Sihwi, S. W., \& Suryani, E. (2014). Analisa Clustering Menggunakan Metode K-Means Dan Hierarchical Clustering.Universitas Sebelas Maret. Surakarta.

[15] Rubiyanto.2005.Evaluasi Pendidikan.Surakarta : Program Akta Mengajar FKIP UMS

[16] Sugiyono, (2008). Metode Penelitian Kunatitatif Kualitatif dan R\&D. Bandung Alfabeta

[17] Triawan, A., \& Sofyan, R. S. (2019). Penerapan Algoritma Booyer Moore Untuk Efisiensi Pencarian Data Letak Kendaraan Pada Aplikasi Gudang Dealer SETIAJAYA TOYOTA. 
Volume 9 Number 2 November 2019 Page. 53-64

Journal Homepage : http://teknois.stikombinaniaga.ac.id/index.php/JBS

DOI Link : http://doi.org/10.36350/jbs.v9i2

TeknoIS : Jurnal Ilmiah Teknologi Informasi Dan Sains. https://doi.org/10.36350/jbs.v7i2.25

[18] Utari, L., \& Agustianto, I. T. (2019). Menghitung Ketepatan Jawaban Soal Ujian Essay dengan Penerapan Algoritma Boyer-Moore. TeknoIS : Jurnal Ilmiah Teknologi Informasi Dan Sains. https://doi.org/10.36350/jbs.v8i2.15

[19] Widodo, D. W.2017. Implementasi Algoritma K-Means Clustering Untuk Mengetahui Bidang Skripsi Mahasiswa Multimedia Pendidikan Teknik Informatika Dan Komputer.Universitas Negeri Jakarta.Jakarta 